\title{
Antibiotic Residue in the Aquatic Environment: Status in Africa
}

https://doi.org/10.1515/chem-2018-0099

received December 19, 2017; accepted May 9, 2018.

Abstract: Information on the presence of antibiotics is sparse for all types of water in Africa, including groundwater, surface water, effluent of wastewater treatment plants (WWTPs) and municipal potable water. With the relatively high sales of different antibiotics to treat infectious diseases in the human population of Africa, the residual of the antibiotics is bound to be released through excretion via urine or fecal matter in parallel to the high sales. This article reviews the published analysis on the occurrence of antibiotics in the environment particularly in the aquatic environment in some countries in Africa. In general, sulfamethoxazole was the most commonly detected in Africa surface water (with eight reports from four countries) at a concentration range of $0.00027-39$ $\mu \mathrm{gL}^{-1}$. Wastewater analysis is believed to give an early warning for preventing epidemics. Thus, we discuss the associated level of antibiotic resistance to some prevalent diseases in Africa whose aetiological agents can develop antibiotic resistance due to exposure to antibiotic residue in water. This is important because of rising population of immuno-deficient African residents ravaged by HIV/AIDS, poor nutrition and less efficient sanitation systems.

Keywords: Antibiotic; Environment; Release; Antibiotic resistance.

\section{Introduction}

Antibiotics are chemicals, which are categorised into three main groups: natural, semi-synthetic and synthetic. They possess the ability either to impede bacterial growth (bacteriostatic) or kill them (bactericidal) [1] and are used in prophylaxis and therapeutics of bacterial induced diseases in both humans and animals. In Africa, opportunistic diseases, such as, tuberculosis (TB), pneumonia and diarrhea are rampant because of immunocompromised conditions predicated by human immunodeficiency virus (HIV) infection (among others), poor sanitation and drug abuse. An increase in the consumption of antibiotics has occurred in order to cure the diseases [2-5], partly without any physician's prescription. Antibiotics are also used extensively in animal farming to maintain the high demand for animal products [6-8]. The high antibiotic consumption in humans and in farm animals [4,9] resulted in increased release of partially metabolized antibiotics into the aquatic environment through wastewater [10]. Most of the antibiotics consumed ends up in sewer system either directly or indirectly, since they are only partially metabolised $[1,11,12]$ or broken down with the active component still intact [13]. Indirect discharge of antibiotics is a result of unintentionally release (via excretion) of consumed antibiotics into the environment. Unconsumed antibiotics are sometimes discarded directly into the sewer system. They are partially degraded but the active components continue to impact the environment, which will eventually enhance resistance in bacteria or may have eco-toxicological effects because of their high concentration [14-16].

\section{Occurrence of antibiotics in aquatic milieu}

Wastewater treatment plants (WWTPs) receive most of the partially metabolised antibiotics from humans via the sewer system, while the rest are either directly dumped into the nearby streams and rivers or escape as seepages
*Corresponding author: A.C. Faleye, Institute for Water and Wastewater Technology, Durban University of Technology, Durban, South Africa; Department of Chemistry, Faculty of Applied Sciences, Durban University of Technology, Durban, South Africa, E-mail: Kunle_faleye@yahoo.co.uk

A.A. Adegoke, Faizal Bux, T. A. Stenström: Institute for Water and Wastewater Technology, Durban University of Technology, Durban, South Africa

K. Ramluckan: Department of Chemistry, Faculty of Applied Sciences, Durban University of Technology, Durban, South Africa

¿ Open Access. ( 2018 A.C. Faleye et al., published by De Gruyter. @) Br-Nc-ND This work is licensed under the Creative Commons AttributionNonCommercial-NoDerivatives 4.0 License. 
from, for example, landfill sites [17]. A general pathway of introduction of antibiotics into the environment is presented in Figure 1. It illustrates the impact of the general society and the eventual contamination of the surface water, which, in the end, affects both drinking water quality and irrigation of crops. Most WWTPs are not configured to remove antibiotics; hence, the antibiotics are released to the aquatic environment from the final treated effluent, making the WWTPs a main hot spot for the release of antibiotics [11,18]. In animal husbandry, manures generated by farm animals are frequently reused as organic fertilizers in farmland and may partially end up in environmental waters through runoff. These waste components contain antibiotics [19] and are major sources of the increase in the concentration of the antibiotics in the aquatic system [20] with attending public health intricacies.

The presence of antibiotics in the aquatic environment, has been confirmed in many reports as emerging contaminants around the world, but the majority of the reports are from outside Africa [10,11,21-23].

\subsection{Global detections of antibiotics}

Globally, antibiotics are detected at varying concentrations in several environmental matrices such as surface waters and sediment. For example, Karthikeyan and Meyer detected six different antibiotics in raw wastewater in USA. Among these, sulfamethazine was reduced from maximum concentration of $0.21 \mu \mathrm{g} / \mathrm{L}$ in the influent concentration to below detection limit in the effluents. Sulfamethoxazole with an influent concentration (maximum concentration) of $1.25 \mu \mathrm{g} / \mathrm{L}$ was reduced to $0.37 \mu \mathrm{g} / \mathrm{L}$ in the effluent. The remaining 4 are tetracycline, ciprofloxacin, erythromycin and trimethoprim, with their concentrations in theinfluent and effluent ranging from $0.21-1.30 \mu \mathrm{g} / \mathrm{L}$ and $0.85-0.14$ $\mu \mathrm{g} / \mathrm{L}$ respectively [24]. In a wastewater treatment plant in China, L.-J Zhou et al. (2013) detected 20 antibiotics in the influent and 17 in the effluent samples, out of which sulfamethoxazole, norfloxacin, ofloxacin, erythromycin and trimethoprim were most frequently detected [25]. The total concentration of antibiotics per capita in one of the plants investigated ranged from around 500 to 900 $\mu \mathrm{g} / \mathrm{d} /$ inhabitant (mean value $670 \mu \mathrm{g} / \mathrm{d} /$ inhabitant) in the influent samples. The corresponding values in the effluent varied from around 130 to $240 \mu \mathrm{g} / \mathrm{d} / \mathrm{inh}$ hbitant (mean $175 \mu \mathrm{g} / \mathrm{d} /$ inhabitant) [25]. Antibiotics have also been detected in drinking water and purified tap water. This is exemplified in a survey of Austrian drinking water in 2014, where sulfamethoxazole was detected at a concentration within a range of $4.4-8.9 \mathrm{ng} / \mathrm{L}$ among many others [26]. Likewise, the presence of 7 sulfonamides, trimethoprim, and 4 macrolides in 37 rivers in Japan was reported [27] and the concentrations were in the range from "not detected" to $630 \mathrm{ng} / \mathrm{L}$ with a median of $7.3 \mathrm{ng} / \mathrm{L}$. Similarly, in a treated effluent in Saudi Arabia, sulfamethoxazole and trimethroprim were reported within the range of $145-730$ $\mathrm{ng} / \mathrm{L}$ and 41- $44 \mathrm{ng} / \mathrm{L}$ (mean concentration) respectively [28]. Other reports include different levels of detection of antibiotics in soil and sediment $[6,29,30]$. Five antibiotics were also detected in plant tissues (chlortetracycline, monensin, sulfamethazine, tylosin, and virginiamycin) with concentrations of $<10 \mu \mathrm{g} \mathrm{kg}^{-1}$ [31].The adaptation of bacteria to the presence of antibiotics in the environment may lead to emergence of resistance [32] as well as for the selection of antibiotic resistance genes which can be transferred to other bacteria via horizontal gene transfer [33]. This contributes to the increase in the occurrence of antibiotic resistant bacteria (ARB) globally [34] as exposure to sub-lethal concentrations of antibiotics or its derivatives induces resistance [35]. The occurrence have been reported in wastewater, rivers and drinking water in China [36], Europe [37] , Australia [38], America [39] and Africa [40].

Adverse effects of the presence of antibiotics in the aquatic environment, especially on fish have been reported [41]. One of the effects, is the suppression of fish immune system by the presence of tetracycline $(0.1-50 \mu \mathrm{g} / \mathrm{L})$ in environment [42]. Norfloxacin and Sulfamethoxazole at a concentration of $200 \mu \mathrm{g} / \mathrm{L}$, has also been reported to have an adverse effect on the growth and reproduction rate of Zebrafish [43]. There is a need to monitor and checkmate the release and persistence of antibiotics in the environment.

\section{Removal of antibiotics from used waters}

The presence and fate of antibiotics in raw wastewater and treated sewage effluents $[12,45]$ are sometimes measured in line with national priorities. In Africa, just a few scattered reports are available, despite the assumed high level of consumption of antibiotics because of high prevalence of infectious diseases $[2,4,23,46]$. Most studies have focused on the prevalence of antibiotic resistant bacteria in sewage effluents, drinking water and water bodies, with no recourse to inducing factors in relation to the presence of antibiotics in such environments. This leaves an information gap about antibiotics as a potential inducer 


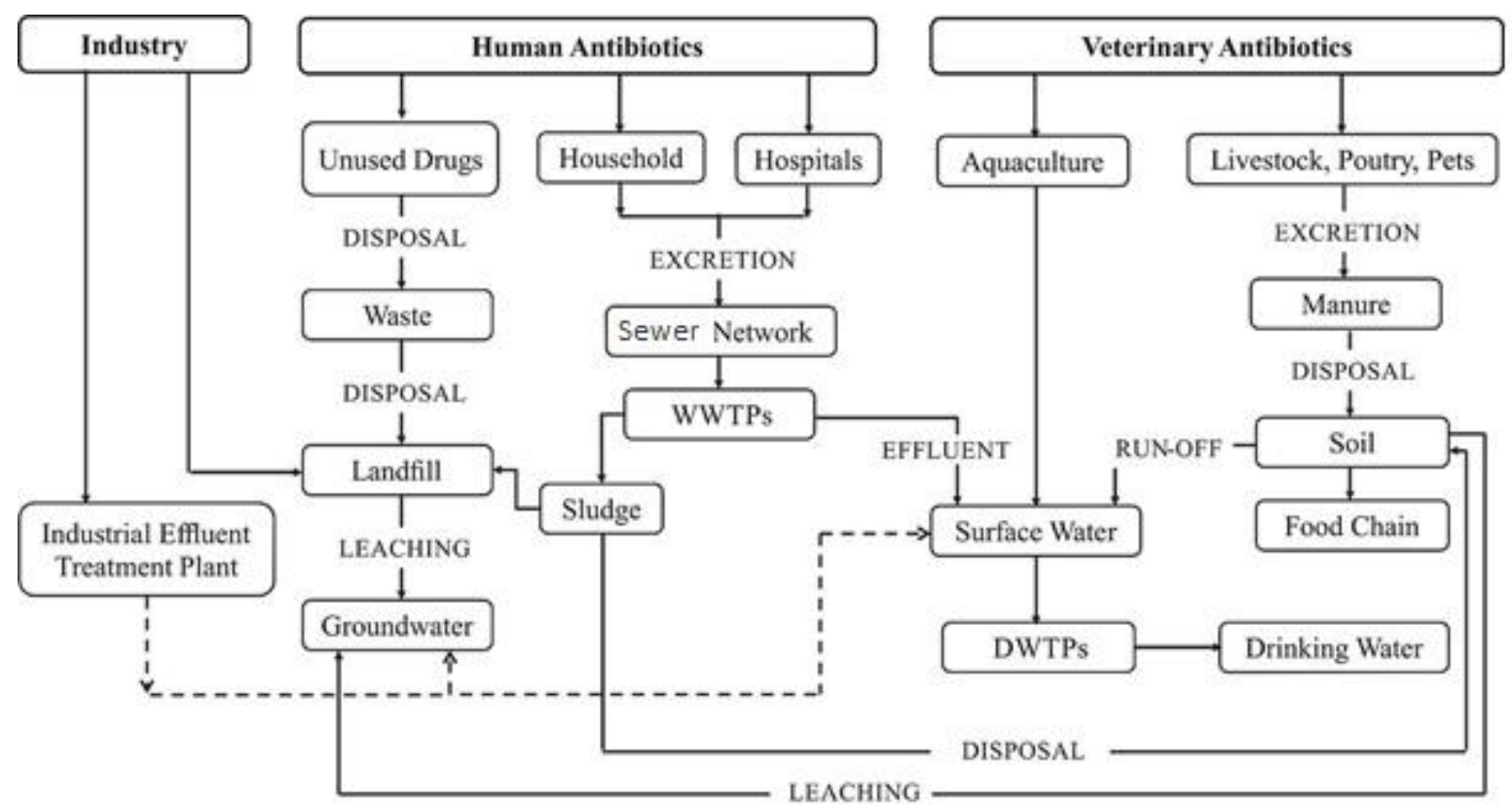

Figure 1: Pathways of antibiotics into the environment [44].

of bacterial resistance. This review gives an overview of available reports of the concentration of antibiotics in the aquatic environment in Africa, their limitations and the need for continuous monitoring of the concentration of the antibiotics discharged into the aquatic environment in relation to antibiotic resistant pathogens.

\section{Origin Of Antibiotics Into The Environment}

Antibiotics in the environment originate from various sources. The impact of human/animal route, sociodemographic route and other routes are described in the following sections.

\subsection{Human/Animal Health Consumption Route Impact}

The human consumption of antibiotics is directly related to the residuals released through sewage and waste products discarded into the environment. Based on the level of disease resistance in Africa, it is assumed that the level of antibiotic consumption is high [47].

The information related to the consumption of antibiotics in African countries are scattered and limited.
South Africa and Kenya have a partial record of the amount of antibiotics consumed by their population $[9,40]$. This partial record is the most comprehensive report on consumption of antibiotics in Africa. Other reports from northern and western Africa are scattered and not comprehensive [4]. Available reports on the global consumption of veterinary related antibiotics with a view on Africa has been documented, giving detailed information on available data on consumption from Kenya only. The report with reference to Mitema et al., reveals that between 1995 to 1999, tetracyclines, sulfonamides and trimethoprim were the most consumed. In South Africa, the quantities of antibiotics prescribed in the private health sector was compiled in a Master's Thesis [48] with a focus on the consumption of fluoroquinolones. The report represents a view on the high rate of consumption of antibiotics in parallel to the prevalent diseases in South Africa.

Detailed information on the use of antibiotics is important for theassessment of the potential concentration ranges that may be released into the environment. This has also been pointed out by the World Health Organisation (WHO) with emphasis on the measurements and monitoring of the volumes and patterns of antibiotics use towards controlling their impact on the environment [49]. In a report on the consumption of antibiotics based on the sales [4] the percentage per capita changes in antibiotics consumption between 2000 - 2010 presented (Figure 2). 


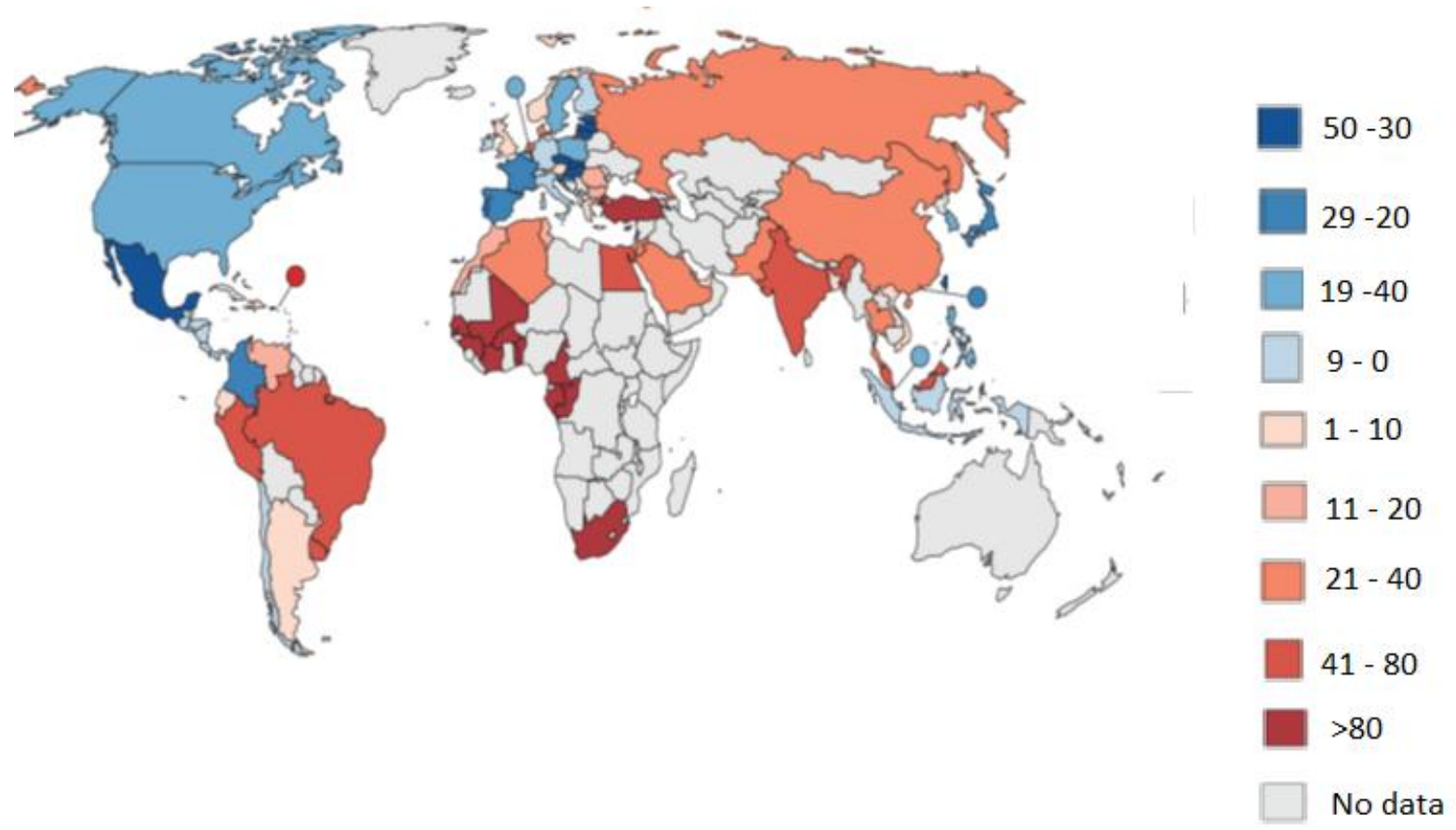

Figure 2: Percentage changes in antibiotics consumption per capita $2000-2010$ by country. The blue colours indicate decreases while the rest are increases. Picture adapted from [4].

20000

15000

Population (per 1000) 10000

5000
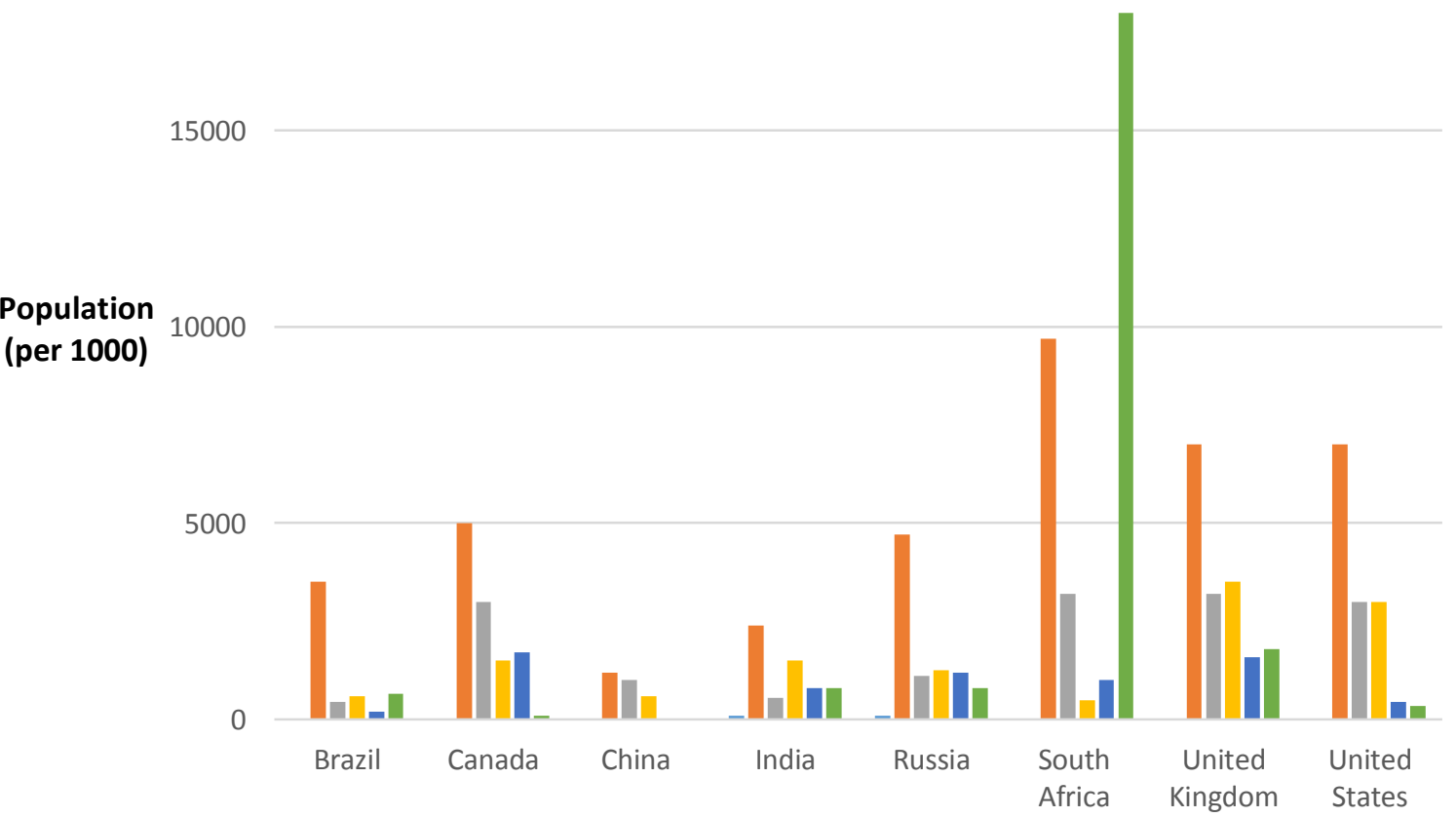

Aminoglycoside Broad spectrum Penicillin $\square$ Macrolides $\square$ Quinolones $\square$ Tetracycline Trimethroprim $\square$

Figure 3: Antibiotics used globally in 2010 based on 1000/population [50]. 
This shows a global increase in antibiotic consumption spearheaded by low and middle income countries and with a major lack of data from major parts of Africa. Western Africa (French speaking) was considered as one unit and the detailed report from Kenya is missing on the map and also in the text.

Sale records of antibiotics used are fairly accurate in South Africa and can be used as an indicator of the rate of consumption. The broad-spectrum penicillin are the most sold with $18.3 \%$ of the antibiotics market followed by penems and carbapenems with $14 \%$ and macrolides with $11.1 \%$ [51].

A report by IMS as shown in Figure 3 summarizes six groups of antibiotics (aminoglycoside, penicillin, macrolides quinolones, tetracycline and trimethoprim) that are mostly used by humans globally. The use of trimethoprim and penicillin was highest in South Africa and this can be justified based on the pharmacological application of the antibiotics. Penicillin is a broadspectrum antibiotic while trimethoprim is more specific, and is used in the treatment of bladder infections. When trimethoprim is used with sulfamethoxazole, it can be used for Pneumocystis pneumonia in people with HIV/ AIDS [52], hence this account for the high rate of sale, and assumed high rate of consumption in South Africa.

The available published report of the use of antibiotics in veterinary medicine is also sparse or lacking for Africa, including South Africa. A report on the mean antibiotics sales per year between 2002 and 2004 are available [53]. In South Africa around 1540 tons of active compounds of five antibiotics were sold. Macrolides and pleuromutilins constituted the major parts of the sales, followed by tetracyclines, sulphonamides and penicillin [53].

The dependence on antibiotics for treatment of bacterial infections has increased over the years, while the bacteria are also constantly evolving in order to adapt to these drugs [54]. This evolution of antibiotic resistance is possibly due to induction through exposure to residual or abused antibiotics. This has led to the development of more resistant bacteria associated with HIV [55]. The scourge of HIV and TB remains of primary concern [56-58] in all reported regions of Africa [59,60], with a direct link to the high rate of HIV infection. Due to a rising proportion of immunocompromised as a result of HIV prevalence, TB has dramatically increased the endemicity of the disease [57]. The world's third largest morbidity of TB is currently in South Africa, driven by HIV infection. In particular, the province of KwaZulu-Natal (KZN) alone accounts for more than $30 \%$ of the reported cases.

As a comparison the Northern Cape Province just had a little above $2.3 \%$ as the least affected province in
South Africa [2]. Out of the over 100,000 reported cases of TB per year in KZN, well above $60 \%$ of the persons are infected with HIV [61]. Invariably, this is associated with high consumption of antituberculosis drugs such as isoniazid and ethionamide (DID, Define Daily Dose per 1000 Inhabitants per Day of 2.41) [48], which in parallel is related to the presence in the environment.

Lung infections caused by bacteria such as Streptococcus pneumoniae is most common in KwaZuluNatal [62]. When it occurs as a secondary infection to HIV, it may sometimes necessitate the use of multiple antibiotics, as single or fixed dose combination therapy (FDCT) to combat the infection. Nassab and Khosravani reported that approximately 450 million people are infected with pneumonia globally on a yearly basis. This is also a cause of child mortality with close to 2 million deaths yearly [63]. More than half of the global death record, as a result of pneumonia, occurs in Africa and pneumonia ranks as the highest killer infection in South Africa [64,65]. For atypical polymicrobial pneumonia, several antibiotics are usually taken by patients before reporting into a hospital. Usually a high-dose amoxicillin (4 g/day) or amoxicillinclavulanate ( $4 \mathrm{~g} /$ day $)$, or a respiratory fluoroquinolone is the first line of approach [66]. However, combinations of antibiotics are used mostly in the treatment for over a minimum period of two weeks [66].

\subsection{Socio-Demographic Impact}

Informal settlement communities in Africa do not always have access to direct potable water and are in many instances exposed to unhygienic domestic water and sanitation conditions. The underlying causes are improper sewage disposal or on-site sanitation systems, open defecation, leading to contamination of water sources that later are used for domestic purposes. These life conditions, in addition to poor nutritional status, enhance the risk for different types of diarrheal infections [67]. Diarrhea can be self-regressive after a few days without treatment [68] among the immune-competent, but may be persistent among the immunocompromised or immunosuppressed individuals. Diarrhea disease are prominent in South Africa among children [67] and it is also closely connected to HIV/AIDS. Persistent diarrhea is usually treated with antibiotics such as metronidazole. The use of this drug is increasing within a growing population that lack basic social amenities [67].

Partially metabolized antibiotics in the environment [34] may increase the development of antibiotics resistant microbes [36,69] and eco-toxic effects [70]. Direct dumping 
of antibiotics into the sewer system also contributes to their increase in the environment. Hamjinda et al. reported that most of the oral drugs used by patients in hospitals are discarded into the sewer system, thereby contributing to the concentration of antibiotics in most hospital wastewater effluents [71]. Likewise, derivatives formed from wastewater treatment reactions may create a more toxic effect than its real natural form [18].

Another important group of antibiotics are the antiparasitic drugs. These are used to treat infections with multicellular parasitic worms (helminths) and unicellular parasites (protozoans). They are of major importance in both human tropical medicine and in veterinary medicine. The presence of the active component of anti-helminthic drugs (AHD) are well documented in animal tissues and products such as milk, liver, muscle, kidney [72-75] but less so from environmental sources.

Considering the high number of animal husbandry farms in many provinces, with reports of AHD resistance rampant in animal farms in South Africa [76,77], the probability of having a high concentration of these drugs in wastewater or their receiving water/sediment is high. There is a significant risk that anti-helminthic agents may affect freshwater organisms negatively in the environment [78,79].These antibiotics are mostly entering the aquatic environment via wash off from grazing farmlands or from where animal manure are applied or stored [80]. In promoting the reasons for the widespread use of drugs to control human helminths, Cerami and Warren suggested that "helminths are less likely to develop resistance or would do so more slowly" compared to other infectious agents because they multiply at a lower rate [81]. This has certainly not appeared true for helminths in livestock, and neither in the treatment of human helminths as well. It is also estimated that some 1.3 to 2.0 billion people in the world suffer from helminthic infections [82,83]. Drug resistant helminths may not be a major health issue yet, but may be of possible future environmental concern.

\section{Current Level Of Threat Associa- ted With Antibiotics' Resistance}

The rate of development of Multidrug Resistant (MDR) and Extensively Drug Resistant (XDR) bacteria is alarming and there is a need for a holistic approach towards the management of the crisis $[84,85]$. Klopper et al.showed that TB bacteria are resistant to the available antibiotics, both first and second line approaches [86]. Likewise MDR pneumonia has been identified [87].
In a recent study from South Africa on MDR TB, the empiric treatment approach (rudimentary treatment without consideration of the environment) in administration of drugs maybe lead to poor therapeutic outcome, thereby fuelling the development of XDR [61]. Different approaches towards the elucidation of the cause of the poor performance of the antibiotics in the treatment of TB seem to have been taken, except the role of residues of antibiotics on microbes in the environment. Antibioticresistant pathogens have been detected in tap water and purified water [88]. In relation to this, the possibility of the influence of resistant pathogens from the environment on the pathogens in an immunocompromised patient may be the reasons for the failure of the drug of approach. Mycobacterium tuberculosis, which is documented in wastewater, may get exposed to the antibiotic residue and develop resistance [89] to form XDR M. tuberculosis. Exposure of the XDR bacteria excreted into wastewater, with the wastewater already containing residual antibiotics in sub-lethal concentrations, might have contributed to the emergence of Total Drug Resistance (TDR). Intermittent surveillance of the residual antibiotics in the environment will contribute to the documentation of emergence of resistance and selection for resistance genes [34].

MDR pneumonia-causing bacteria have been reported in South Africa [87]. Cases of gradual increase in threat level of resistance towards antibiotics in the treatment of different diseases have been reported and are exemplified in Table 1. Exposure of pneumonia bacteria to subinhibitory concentration of antibiotic residues in the environment may play vital role in the emergence of the MDR.

The resistance to antibiotics used in the treatment of pneumonia was compared between 2007 and 2014 in South Africa [92] and a gradual increase was noticed. Cefotaxime increased from $46 \%$ to $68 \%$, Cefepime from $44 \%$ to $68 \%$ and Ciprofloxacin from $31 \%$ to $46 \%$ [91,92]. This increase may not represent a general trend, but there is in fact an increase in the rate of resistance that should not be overlooked.

A study conducted on children under five years in Mozambique showed a steady build-up of resistance to all antibiotics used in treatment of diarrhea caused by Shigella bacteria [96] (Table 1). In an extensive review on the antibiotic resistance of Shigella across Europe, Asia and Africa, it was reported that the rapidly rising trend of antibiotic resistance were similar, with resistance towards the second line of the antibiotics [97]. One of the recommendations made at checkmating these increases in antibiotic resistance is to intensify research towards 
Table 1: Some bacterial diseases and reported antibiotic resistant statues.

\begin{tabular}{|c|c|c|c|c|}
\hline $\begin{array}{l}\text { Diseases (causative } \\
\text { bacteria) }\end{array}$ & $\begin{array}{l}\text { Current stage } \\
\text { of resistance to } \\
\text { antibiotics }\end{array}$ & $\begin{array}{l}\text { Drug of approach (percentage } \\
\text { resistance) }\end{array}$ & Study location & References \\
\hline $\begin{array}{l}\text { Pneumonia (Klebsiella } \\
\text { pneumoniae) }\end{array}$ & MDR & $\begin{array}{l}\text { Amoxicillin (99), Amox/clav (14), } \\
\text { Cefuroxime (27), Cotrimoxazole (11) }\end{array}$ & $\begin{array}{l}\text { Gauteng, Western cape, } \\
\text { Eastern cape, Kwazulu-Natal, } \\
\text { Mpumulanga, and Orange free } \\
\text { state provinces in South Africa }\end{array}$ & {$[90]$} \\
\hline $\begin{array}{l}\text { Pneumonia (Klebsiella } \\
\text { pneumoniae) }\end{array}$ & MDR & $\begin{array}{l}\text { Ampicillin (98), Cefuroxime (52) } \\
\text { Ceftriaxone/cefotaxime (46) } \\
\text { Cefepime (44), } \\
\text { Co-amoxiclav (52) } \\
\text { Piperacillin-tazobactam (40) } \\
\text { Ciprofloxacin (31) } \\
\text { Levofloxacin (32), Ertapenem (2) } \\
\text { Imipenem (0), Meropenem (0) }\end{array}$ & $\begin{array}{l}\text { Johannesburg, Pretoria, Durban, } \\
\text { Cape Town and Bloemfontein all } \\
\text { in South Africa }\end{array}$ & [91] \\
\hline $\begin{array}{l}\text { Pneumonia (Klebsiella } \\
\text { pneumoniae) }\end{array}$ & MDR & $\begin{array}{l}\text { Cefotaxime (68.3), Carbapenens (4.5), } \\
\text { Piperacillin/tazobactam (33.1), } \\
\text { Ceftazidime (68.3), } \\
\text { Cefepime(68.3), } \\
\text { Ciprofloxacin (46.5) }\end{array}$ & $\begin{array}{l}\text { Gauteng, KwaZulu-Natal, Free } \\
\text { State, Limpopo and Western } \\
\text { Cape provinces of South Africa }\end{array}$ & [92] \\
\hline $\begin{array}{l}\text { Pneumonia } \\
\text { (Streptococcus } \\
\text { pneumoniae) }\end{array}$ & MDR & $\begin{array}{l}\text { Ampicillin (74), Chloramphenicol (55), } \\
\text { Cotrimoxazole (66), Gentamicin (16), } \\
\text { Chloramphenicol (35), Ampicillin plus } \\
\text { gentamicin (14), } \\
\text { Penicillin plus gentamicin (11), } \\
\text { Chloramphenicol plus ampicillin (29). }\end{array}$ & $\begin{array}{l}\text { Maputo Provinces in Southern } \\
\text { Mozambique }\end{array}$ & [93] \\
\hline $\begin{array}{l}\text { Pneumonia } \\
\text { (Streptococcus } \\
\text { pneumoniae) }\end{array}$ & MDR & $\begin{array}{l}\text { Penicillin (46), } \\
\text { amoxicillin (7), } \\
\text { Amox/clav (5), } \\
\text { Cefuroxime (53), Azithromycin (61), } \\
\text { Clarithromycin (61), Cotrimoxazole (51) }\end{array}$ & $\begin{array}{l}\text { Gauteng, western cape, } \\
\text { Eastern cape, Kwazulu-Natal, } \\
\text { Mpumalanga, and Orange free } \\
\text { state provinces in South Africa }\end{array}$ & [90] \\
\hline $\begin{array}{l}\text { Pneumonia } \\
\text { (Streptococcus } \\
\text { pneumoniae) }\end{array}$ & MDR & $\begin{array}{l}\text { Chloramphenicol (33), Clindamycin (10), } \\
\text { Erythromycin (1.5), Gentamicin (85.2), } \\
\text { Oxacillin (18.6), Tetracycline (50.8), } \\
\text { Trimethroprime (89.4) }\end{array}$ & Lilongwe district Malawi. & [94] \\
\hline $\begin{array}{l}\text { Shigellosis } \\
\text { a. (S. flexneri type } 2 \mathrm{a}) \text {, } \\
\text { b. (S. flexneri type } 1 \mathrm{~b})\end{array}$ & MDR & $\begin{array}{l}\text { Ampicillin a (66.3), b (85.4) } \\
\text { Chloramphenicol a (47.2), b (77.1) } \\
\text { Streptomycin a (69.7), b (85.4) } \\
\text { Sulfamethoxazole a (91.0) } \\
\text { Trimethoprim a (94.4), b (75.0) } \\
\text { Tetracycline a (60.7), b (100) } \\
\text { Nalidixic Acid a (1.1), b (89.6) } \\
\text { Ciprofloxacin a (0), b (0) } \\
\text { b-lactamase based a (2.3), b (2.1) }\end{array}$ & $\begin{array}{l}\text { All nine provinces in South } \\
\text { Africa }\end{array}$ & [95] \\
\hline Shigellosis & MDR & $\begin{array}{l}\text { Ciprofloxacin(0), Ceftriaxone (0) Co- } \\
\text { Trimoxazole (83), Tetracycline (72), } \\
\text { Ampicillin (26). }\end{array}$ & Gauteng, South Africa & [23] \\
\hline Shigellosis & MDR & $\begin{array}{l}\text { Chloramphenicol (52), Ampicillin (56), } \\
\text { Tetracycline (66), } \\
\text { Trimethoprim (84), Sulfamethoxazole } \\
\text { (84). }\end{array}$ & $\begin{array}{l}\text { Southern Mozambique, } \\
\text { Mozambique. }\end{array}$ & [96] \\
\hline
\end{tabular}


identifying and removal of sub lethal concentration of antibiotics or their active components from the environment, particularly in wastewater [49]

\section{Detection Of Antibiotics In Aquatic Environment}

Among African countries, South Africa is the country with the highest number of studies monitoring antibiotic use (Table 2). Still, antibiotics in the aquatic environment of South Africa has only been addressed in a limited number of studies and not directly been compared to the level of infectious diseases. Likewise globally, such comparisons are few. Only ten antibiotics, out of the numerous antibiotics consumed have been detected in two out of the nine South African provinces. Their concentrations and references are displayed in Table 2. The information from other African countries are even more limited. There are only 15 published studies having a limited amount of information, despite generally high sales/consumption on the African continent.

An important factor related to the information of antibiotics detected in a country is the sampling coverage area. Analysing a large number of antibiotics from different geographical locations gives more information about the environmental concentration within the country. This is much better than identifying a large number of antibiotics in one sampling spot. For example, a total of 13 antibiotics have been identified in Nigeria representing two sampling areas in the Western region of Nigeria [103,104]. In the first report, only one antibiotic was detected by Olaitan et al., and in the second report, 12 antibiotics were identified by Olarinmoye et al. [103,104]. Based on the sampling, only from the Western region, this report cannot represent the level of antibiotics in the whole country. Nigeria is the most populated country in Africa with a large proportion living on below $\$ 1$ per day [97]. Such low income standards are associated with malnutrition, high diseases burden, and correlated with high rate of drug consumption [110]. Hence one would assume that further reports would be available, based on the influencing factors and accounting for the antibiotics on this large population. Reports on the environmental presence of antibiotics from other West African countries are also largely lacking. From the North African countries, reports are available from Morocco, Tunisia and Egypt [105-108]. Analyses were performed on potable water in Morocco with one antibiotic detected. In Egypt and Tunisia, three and sixteen antibiotics were detected respectively in wastewater samples. The first five antibiotics detected in Tunisia [106] were identified in wastewater at $\mathrm{ng} / \mathrm{L}$ levels of concentration, while the remaining 11 antibiotics were detected in wastewater/ seawater in $\mathrm{ng} / \mathrm{mL}$ [107]. The differences in the results of the analyses cannot be compared because, different antibiotics were analysed. East Africa is represented by the analysis of 10 antibiotics from Kenya, while in Southern Africa, 11 antibiotics were detected (South Africa with 10 antibiotics and Zimbabwe with 1 antibiotic).

A different range of concentration of antibiotics was reported by United Nations (UN) global surface water assessment for pharmaceuticals, when compared to the reported concentrations in Africa [111]. For example, sulfamethoxazole, the most reported antibiotic, was reported in South Africa at a concentration of $7.3 \mu \mathrm{gL}^{-1}$ [46], while in Nigeria the reported concentration was $1.5 \mu \mathrm{gL}^{-1}$ [103] while the minimum and the maximum concentrations reported in Africa were at a concentration of $0.00027 \mu \mathrm{gL}^{-1}$ in Tunisia and $40 \mu \mathrm{gL}^{-1}$ in Kenya [102], respectively. However, the minimum and maximum concentrations reported by the UN were in the range of 0.1 - $29 \mu \mathrm{gL}^{-1}$, respectively [111]. Likewise, ciprofloxacin was reported within the range of $19-6500 \mu g \mathrm{~L}^{-1}$ by the UN [111] and $0.0002-15 \mu \mathrm{gL}^{-1}$ in Africa from Tunisia [106] and South Africa [23], respectively. These measurements do not correlate with concentrations detected in Africa because most of the measurements used for the calculation were made without reports from Africa, as there are few reports from the continent.

Globally, Quinolones and flouroquinolones are antibiotics that are frequently used for the treatment of bacterial infections and they are also among the five ( $\beta$-lactam, macrolides, fluoroquinolones, sulfonamides, and tetracyclines) most commonly detected in the environment [112]. In a study on a wastewater reclamation plant (WRP) in Beijing, China, [113], $0.1 \mu g \mathrm{~L}^{-1}$ of flouroquinolones were detected at the tertiary effluent. The concentration was similar to findings in South Africa by R. Hendricks and E.J. Pool but much lower than what was found in the surface/sediment analysis $\left(15 \mu \mathrm{gL}^{-1}\right.$ and $190 \mu \mathrm{g} / \mathrm{g}$ ) by Agunbiade and Moodley [23,98].

Further information on the detection of antibiotics within the African environment will be beneficial for several reasons: 1) To answer questions related to correlations of population density and socio-economic strata as compared to consumption of antibiotics and concentrations in surface water and ground water; 2) To relate sewer system and poor method of sewage disposal with different barriers and release routes of residual antibiotics in the wastes. This may also contribute to an assessment of the accumulation of antibiotics in the 
Table 2: Antibiotics and their detected maximum concentrations reported in the environment in Africa (the number of significant digits has been reduced from what was stated in the respective reference).

\begin{tabular}{|c|c|c|c|c|}
\hline Sample sources & Study location & Antibiotics (Class) & Maximum Conc. & Literature \\
\hline $\begin{array}{l}\text { Treated sewage } \\
\text { Effluents }\left(\mu \mathrm{gL}^{-1}\right)\end{array}$ & South Africa & $\begin{array}{l}\text { Fluoroquinolones (Quinolones) } \\
\text { Sulfamethoxazole (Sulfonamide) }\end{array}$ & $\begin{array}{l}0.12 \\
0.15\end{array}$ & [98] \\
\hline Surface water $\left(\mu \mathrm{gL}^{-1}\right)$ & South Africa & $\begin{array}{l}\text { Ampicillin (Penicillin) } \\
\text { Ciprofloxacin (Quinolones) } \\
\text { Nalidixic acid (Quinolones) }\end{array}$ & $\begin{array}{l}16 \\
15 \\
23.50\end{array}$ & [23] \\
\hline 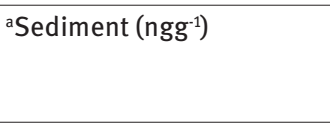 & South Africa & $\begin{array}{l}\text { Ampicillin (Penicillin) } \\
\text { Ciprofloxacin (Quinolones) } \\
\text { Nalidixic acid (Quinolones) }\end{array}$ & $\begin{array}{l}\mathrm{a} 467 \\
\mathrm{a} 187 \\
\mathrm{a} 104\end{array}$ & [23] \\
\hline $\begin{array}{l}\text { Surface water }\left(\mu \mathrm{gL}^{-1}\right) / \\
\text { aSediment }\left(\mathrm{ngg}^{-1}\right)\end{array}$ & South Africa & $\begin{array}{l}\text { Sulfamethoxazole (Sulfonamide) } \\
\text { Erythromycin (Macrolide) } \\
\text { Sulfamethazine (Sulfonamide) } \\
\text { Metronidazole (Nitroimidazole) } \\
\text { Trimethoprim (Trimethoprim) }\end{array}$ & $\begin{array}{l}7.3 /{ }^{\mathrm{a}} 50 \\
20 /{ }^{\mathrm{a}} 16 \\
33 / \mathrm{a} N D \\
\mathrm{ND} /{ }^{\mathrm{a}} 63 \\
3.70 /{ }^{\mathrm{a}} \mathrm{ND}\end{array}$ & [46] \\
\hline $\begin{array}{l}\text { Surface water }\left(\mu \mathrm{gL}^{-1}\right) / \\
{ }^{\text {aSediment }}\left(\mathrm{ngg}^{-1}\right)\end{array}$ & South Africa & $\begin{array}{l}\text { Sulfamethoxazole (Sulfonamide) } \\
\text { Erythromycin (Macrolide) } \\
\text { Sulfamethazine (Sulfonamide) } \\
\text { Metronidazole (Nitroimidazole) } \\
\text { Trimethoprim (Trimethoprim) }\end{array}$ & $\begin{array}{l}6 /{ }^{\mathrm{a}}<\mathrm{MDL} \\
13.6 /{ }^{\mathrm{a}}<\mathrm{MDL} \\
4.6 /{ }^{\mathrm{a}} \mathrm{ND} \\
\mathrm{ND} /{ }^{\mathrm{a}} 130 \\
0.80 /{ }^{\mathrm{a}} 92\end{array}$ & [46] \\
\hline River water $\left(\mu \mathrm{gL}^{-1}\right)$ & South Africa & Nalidixic acid (Quinolones) & 3.0 & [99] \\
\hline Surface water $\left(\mu \mathrm{gL}^{-1}\right)$ & South Africa & $\begin{array}{l}\text { Azithromycin (Macrolide } \\
\text { Clarithromycin (Macrolide } \\
\text { Sulfamethoxazole (Sulfonamide) } \\
\text { Sulfasalazine (Sulfonamide) } \\
\text { Trimethoprim (Trimethoprim) }\end{array}$ & $\begin{array}{l}0.03 \\
0.30 \\
1.31 \\
0.07 \\
1.20\end{array}$ & [100] \\
\hline $\begin{array}{l}\text { River water/ Wastewater } \\
\left(\mu \mathrm{gL}^{-1}\right)\end{array}$ & Kenya & $\begin{array}{l}\text { Sulfamethoxazole (Sulfonamide) } \\
\text { Ciprofloxacin (Quinolones) } \\
\text { Trimethoprim (Trimethoprim) }\end{array}$ & $\begin{array}{l}14 / 3 \\
0.50 / 0.07 \\
2.70 / 0.07\end{array}$ & [101] \\
\hline $\begin{array}{l}\text { River water/ Wastewater } \\
\left(\mu \mathrm{gL}^{-1}\right)\end{array}$ & Kenya & $\begin{array}{l}\text { Chloramphenicol (Amphenicol) } \\
\text { Ciprofloxacin (Quinolones) } \\
\text { Levofloxacin (Quinolones) } \\
\text { Metronidazole (Nitroimidazole) } \\
\text { Nalidixic acid (Quinolones) } \\
\text { Sulfadoxine (Sulfonamide) } \\
\text { Sulfamethazine (Sulfonamide) } \\
\text { Sulfamethoxazole(Sulfonamide) } \\
\text { Trimethoprim (Trimethoprim) }\end{array}$ & $\begin{array}{l}0.70 / 0.20 \\
\text { ND / 0.30 } \\
0.04 / 1.60 \\
4 / 3 \\
\text { ND / } 2.80 \\
1460 / 3.20 \\
0.60 / N D \\
40 / 10 \\
7 / 4\end{array}$ & {$[102]$} \\
\hline $\begin{array}{l}\text { River water }\left(\mu \mathrm{gL}^{-1}\right) / \\
\text { aSediment }\left(\mathrm{ngg}^{-1}\right)\end{array}$ & Nigeria & $\begin{array}{l}\text { Chloramphenicol (Amphenicol) } \\
\text { Chlortetracycline (Tetracycline) } \\
\text { Clarithromycin (Macrolide) } \\
\text { Doxycycline (Tetracycline) } \\
\text { Erythromycin (Macrolide) } \\
\text { Oxytetracycline (Tetracycline) } \\
\text { Roxithromycin (Macrolide) } \\
\text { Sulfadiazine (Sulfonamide) } \\
\text { Sulfadimidine (Sulfonamide) } \\
\text { Sulfamethoxazole (Sulfonamide) } \\
\text { Tetracycline (Tetracycline) } \\
\text { Trimethoprim (Trimethoprim) } \\
\text { Azithromycin (Macrolide) }\end{array}$ & $\begin{array}{l}0.40 / \text { a ND } \\
0.10 /{ }^{a} \mathrm{ND} \\
0.10 /{ }^{\mathrm{a}} \mathrm{a} \\
0.10 /{ }^{\mathrm{a}} \mathrm{ND} \\
1 /{ }^{\mathrm{a}} 147 \\
0.10 /{ }^{\mathrm{a} N D} \\
0.02 / \mathrm{a} 10 \\
0.04 \\
0.01 \\
1.50 / \mathrm{a} 11 \\
0.10 \\
0.40 / \mathrm{a} 38 \\
\mathrm{ND} /{ }^{\mathrm{a}} 10\end{array}$ & [103] \\
\hline $\begin{array}{l}\text { Ground and Surface water } \\
\left(\mu \mathrm{gL}^{-1}\right)\end{array}$ & Nigeria & Ciprofloxacin (Quinolones) & 0.90 & [104] \\
\hline +Wastewater $\left(\mu g \mathrm{~L}^{-1}\right)$ & Egypt & $\begin{array}{l}\text { Amoxicillin (Penicillin) } \\
\text { Ampicillin (Penicillin) } \\
\text { Dicloxacillin (Penicillin) }\end{array}$ & $\begin{array}{l}99400.0 \\
70600.0 \\
119400.0\end{array}$ & [105] \\
\hline
\end{tabular}


continued Table 2: Antibiotics and their detected maximum concentrations reported in the environment in Africa (the number of significant digits has been reduced from what was stated in the respective reference).

\begin{tabular}{lllll}
\hline Sample sources & Study location & Antibiotics (Class) & Maximum Conc. & Literature \\
\hline${ }^{++}$Wastewater & Tunisia & Erythromycin (Macrolide) & $<0.01$ \\
$\left(\mu \mathrm{LL}^{-1}\right)$ & & Clarithromycin (Macrolide) & $<0.01$ \\
& & Ofloxacin (Quinolones) & $<0.01$ \\
& & Ciprofloxacin (Quinolones) & $<0.01$ \\
& & Sulfamethoxazole (Sulfonamide) & $<0.01$ \\
\hline Wastewater / Seawaters & Tunisia & Chloramphenicol (Amphenicol) & $3.30 / 15.60$ \\
$\left(\mu g L^{-1}\right)$ & & Thiamphenicol (Amphenicol) & $1.20 / \mathrm{ND}$ & {$[107]$} \\
& & Florfenicol (Amphenicol) & $3.30 / 18.4$ \\
& & Paromycin (Aminoglycoside) & $4.2 / \mathrm{ND}$ \\
& & Kanamycin (Macrolide) & $7.50 / 1.50$ \\
& & Aparamycin (Aminoglycoside) & $1.50 / 1.80$ \\
& & Streptomycin (Aminoglycoside) & $2.70 / 3.40$ \\
& & Amikacin (Aminoglycoside) & $2.30 / 1.20$ \\
& & Sisomycin (Aminoglycoside) & $6.70 / 0.40$ \\
\hline Potable water $\left(\mu \mathrm{gL}^{-1}\right)$ & Morocco & Neomycin (Aminoglycoside) & $16.4 / 0.70$ \\
\hline Surface water $\left(\mu \mathrm{gL}^{-1}\right)$ & Zimbabwe & Sulfamethoxazole (Sulfonamide) & $1.60 / 1.40$ \\
\hline
\end{tabular}

${ }^{+}=$Concentration was originally in $\mathrm{mg} / \mathrm{L},{ }^{++}=$Concentration was originally in $\mathrm{ngL}^{-1}, \mathrm{ND}=$ Not detected, ${ }^{\mathrm{a}}=$ sediment sample

environment;3) To promote laboratory capacity which may be essential for future assessment of the environmental presence and impact of pharmaceuticals in general.

\section{Conclusion}

Efforts to address the misuse and overuse of antibiotics in both the human and animal health sectors in Africa must be intensified to sustain the efficacy of the remaining potent antibiotics. Creating more awareness about the negative impact of misuse in relation to antibiotic resistance would reduce drug abuse to a large extent. Antibiotics released into wastewater have to beappropriately tracked. Thesewer system must include facilities with modern wastewater treatment technology, which will be focused towards the removal of antibiotics and other nanocontaminants from wastewater, while already exposed microbes should be totally exterminated from treated water, with the use of post-treatment technology, before use.

Acknowledgements: This work was supported by the National Research Foundation and the SARChI Chair, Institute of Water and Wastewater Technology, Durban University of Technology, Durban, South Africa. Special thanks to Prof Gustaf Olsson, Industrial Automation, Lund University, Sweden, for his editorial assistance.
Conflict of interest: The authors declare no conflict of interest.

\section{References}

[1] Korzybski T., Kowszyk-Gindifer Z., Kurylowicz W., Antibiotics: origin, nature and properties, Elsevier, 2013.

[2] Middelkoop K., Mathema B., Myer L., Shashkina E., Whitelaw A., G. Kaplan, et al., Transmission of tuberculosis in a South African community with a high prevalence of HIV infection, J. Infect. Dis., 2015, 211, 53-61.

[3] Byass P., Interplay between childhood pneumonia and HIV infection, Lancet Infect. Dis., 2014, 14, 1172-1173.

[4] Van Boeckel T.P., Gandra S., Ashok A., Caudron Q., Grenfell B.T., Levin S.A., et al., Global antibiotic consumption 2000 to 2010: an analysis of national pharmaceutical sales data, Lancet Infect. Dis., 2014, 14, 742-750.

[5] Hart C., Kariuki S., Antimicrobial resistance in developing countries, BMJ., 1998, 317, 647-650.

[6] Jechalke S., Heuer H., Siemens J., Amelung W., Smalla K., Fate and effects of veterinary antibiotics in soil, Trends Microbiol., 2014, 22, 536-545.

[7] Jobbins S.E., Alexander K.A., From whence they cameantibiotic-resistant Escherichia coli in African wildlife, J. Wildl. Dis., 2015, 51, 811-820.

[8] T.P. Van Boeckel, C. Brower, M. Gilbert, B.T. Grenfell, S.A. Levin, T.P. Robinson, A. Teillant, R. Laxminarayan, Global trends in antimicrobial use in food animals, Proc. Natl. Acad. Sci. U.S.A., 2015, 112, 5649-5654. 
[9] T. Boyles, V. Naicker, N. Rawoot, P. Raubenheimer, B. Eick, M. Mendelson, Sustained reduction in antibiotic consumption in a South African public sector hospital: Four-year outcomes from the Groote Schuur Hospital antibiotic stewardship programme, S. Afr. Med. J., 2017, 107, 115-118.

[10] Fick J., Lindberg R.H., Fång J., Magnér J., Kaj L., BrorströmLundén E., Screening 2014: Analysis of pharmaceuticals and hormones in samples from WWTPs and receiving waters, IVL Swedish Environmental Research Institute, Stockholm, 2015.

[11] Milić N., Milanović M., Letić N.G., Sekulić M.T., Radonić J., Mihajlović I., et al, Occurrence of antibiotics as emerging contaminant substances in aquatic environment, Int. J. Environ. Health Res., 2013, 23, 296-310.

[12] Manzetti S., Ghisi R., The environmental release and fate of antibiotics, Mar. Pollut. Bull., 2014, 79, 7-15.

[13] Kümmerer K., Pharmaceuticals in the Environment, Annu. Rev. Environ. Resour., 2010, 35, 57-75.

[14] Hidalgo I.J., Assessing the absorption of new pharmaceuticals, Curr. Top. Med. Chem., 2001, 1, 385-401.

[15] Zhang H., Luo Y., Zhou Q., Research advancement of ecotoxicity of tetracycline antibiotics, J. Agric. Environ. Sci., 2008, 27, 407-413.

[16] Aiken A.M., Allegranzi B., Scott J.A., Mehtar S., Pittet D., Grundmann H., Antibiotic resistance needs global solutions, Lancet Infect. Dis., 2014, 14, 550-551.

[17] Tadesse T., Solid and Hazardous Waste Management, USAID, 2004.

[18] Jelic A., Gros M., Ginebreda A., Cespedes-Sánchez R., Ventura F., Petrovic M., et al., Occurrence, partition and removal of pharmaceuticals in sewage water and sludge during wastewater treatment, Water Res., 2011, 45, 1165-1176.

[19] Baguer A.J., Jensen J., Krogh P.H., Effects of the antibiotics oxytetracycline and tylosin on soil fauna, Chemosphere, 2000, 40, 751-757.

[20] Kemper N., Veterinary antibiotics in the aquatic and terrestrial environment, Ecol. Indic., 2008, 8, 1-13.

[21] Hirsch R., Ternes T., Haberer K., Kratz K.-L., Occurrence of antibiotics in the aquatic environment, Sci. Total Environ., 1999, 225, 109-118.

[22] Kümmerer K., Antibiotics in the aquatic environment-a review-part I, Chemosphere, 2009, 75, 417-434.

[23] Agunbiade F.O., Moodley B., Pharmaceuticals as emerging organic contaminants in Umgeni River water system, KwaZuluNatal, South Africa, Environ. Monit. Assess., 2014, 186, 72737291

[24] Karthikeyan K., Meyer M.T., Occurrence of antibiotics in wastewater treatment facilities in Wisconsin, USA, Sci. Total Environ., 2006, 361, 196-207.

[25] Zhou L.-J., Ying G.-G., Liu S., Zhao J.-L., Yang B., Chen Z.-F., et al., Occurrence and fate of eleven classes of antibiotics in two typical wastewater treatment plants in South China, Sci. Total Environ., 2013, 452, 365-376.

[26] Inreiter N., Huemer B., Springer B., Humer F., Allerberger F., Antibiotics in Austrian drinking water resources, survey 2014, Bodenkultur, 2016, 67, 35-43.

[27] Murata A., Takada H., Mutoh K., Hosoda H., Harada A., Nakada N., Nationwide monitoring of selected antibiotics: distribution and sources of sulfonamides, trimethoprim, and macrolides in Japanese rivers, Sci. Total Environ., 2011, 409, 5305-5312.
[28] Alidina M., Hoppe-Jones C., Yoon M., Hamadeh A.F., Li D., Drewes J.E., The occurrence of emerging trace organic chemicals in wastewater effluents in Saudi Arabia, Sci. Total Environ., 2014, 478, 152-162.

[29] Krogh K.A., Björklund E., Fink G., Loeffler D., Halling-Sørensen B., Ternes T.A., Development of an analytical method to determine avermectins in water,sediments and soils using liquid chromatography-tandem mass spectrometry, J. Chromatogr. Sci., 2008, 1211, 60-69.

[30] Gibs J., Heckathorn H.A., Meyer M.T., Klapinski F.R., Alebus M., Lippincott R.L., Occurrence and partitioning of antibiotic compounds found in the water column and bottom sediments from a stream receiving two wastewater treatment plant effluents in Northern New Jersey, 2008, Sci. Total Environ., 2013, 458, 107-116.

[31] D.H. Kang, S. Gupta, C. Rosen, V. Fritz, A. Singh, Y. Chander, H. Murray, C. Rohwer, Antibiotic uptake by vegetable crops from manure-applied soils, J. Agric. Food Chem., 2013, 61, 9992 10001.

[32] McEwen S.A., Fedorka-Cray P.J., Antimicrobial use and resistance in animals, Clin. Infect. Dis., 2002, 34, 93-106.

[33] Rizzo L., Manaia C., Merlin C., Schwartz T., Dagot C., Ploy M.C., et al., Urban wastewater treatment plants as hotspots for antibiotic resistant bacteria and genes spread into the environment: A review, Sci. Total Environ., 2013, 447, 345-360.

[34] Pruden A., Larsson D.G.J., Amézquita A., Collignon P., Brandt K.K., Graham D.W.,et al., Management Options for Reducing the Release of Antibiotics and Antibiotic Resistance Genes to the Environment, Environ. Health Perspect., 2013, 121, 878885.

[35] Gillings M.R., Evolutionary consequences of antibiotic use for the resistome, mobilome and microbial pangenome, Front. Microbiol., 2013, 4, https://www.frontiersin.org/ articles/10.3389/fmicb.2013.00004/full.

[36] Jiang L., Hu X., Xu T., Zhang H., Sheng D., Yin D., Prevalence of antibiotic resistance genes and their relationship with antibiotics in the Huangpu River and the drinking water sources, Shanghai, China, Sci. Total Environ., 2013, 458-460, 267-272.

[37] Böckelmann U., Dörries H.H., Ayuso-Gabella M.N., De Marçay M.S., Tandoi V., Levantesi C., et al., Quantitative PCR monitoring of antibiotic resistance genes and bacterial pathogens in three European artificial groundwater recharge systems., Appl. Environ. Microbiol., 2009, 75, 154-163.

[38] Bruce G.M., PLEUS R.C., NYDER S.A., Toxicological relevance of pharmaceuticals in drinking water., Environ. Sci. Technol., 2010, 44, 5619-5626.

[39] Brinklov S., Kalko E.K.V., Surlykke A., Intense echolocation calls from two 'whispering' bats, Artibeus jamaicensis and Macrophyllum macrophyllum (Phyllostomidae), J. Exp. Biol., 2009, 212, 11-20.

[40] Mitema E., Kikuvi G., Surveillance of the overall use of antimicrobial drugs in humans over a 5 year period (19972001) in Kenya, J. Antimicrob. Chemother., 2004, 54, 966-967.

[41] Corcoran J., Winter M.J., Tyler C.R., Pharmaceuticals in the aquatic environment: a critical review of the evidence for health effects in fish, Crit. Rev. Toxicol., 2010, 40, 287- 304.

[42] Grondel J.L., Gloudemans A.G., Van Muiswinkle W.B., The influence of antibiotics on the immune system II. Modulation 
of fish leukocyte responses in culture., Vet. Immunol. Immunopathol., 1985, 9, 251-260.

[43] Yan Z., Lu G., Ye Q., Liu J., Long-term effects of antibiotics, norfloxacin, and sulfamethoxazole, in a partial life-cycle study with zebrafish (Danio rerio): effects on growth, development, and reproduction, Environ. Sci. Pollut. Res., 2016, 23, 1822218228.

[44] Frade V.M.F., Dias M., Teixeira A.C.S.C., Palma M.S.A., Environmental contamination by fluoroquinolones, Braz. J. Pharm. Sci., 2014, 50, 41-54.

[45] dos Santos Junior H.L., da Silva G.L., da Silva V.L., Qualitative analysis of the presence of emerging contaminants in water supplies for human use: a case study of the Guilherme de Azevedo reservoir in Caruaru (PE, Brazil), Int. J. Adv. Oper. Manag., 2014, 6, 101-109.

[46] Matongo S., Birungi G., Moodley B., Ndungu P., Occurrence of selected pharmaceuticals in water and sediment of Umgeni River, KwaZulu-Natal, South Africa, Environ. Sci. Pollut. Res., 2015, 22, 10298-10308.

[47] MacKenzie F.M., Gould I.M., Quantitative measurement of antibiotic use, In: Gould I.M., van der Meer J.W.M. (Eds.), Antibiotic policies: Theory and practice, Kluwer Academic, New York, NY, 2005.

[48] Agyakwa W.E., Thesis, Potchefstroom Campus of the NorthWest University, 2014.

[49] The Selection and Use of Essential Medicines: Report of the WHO Expert Committee, 2015 (including the 19th WHO Model List of Essential Medicines and the 5th WHO Model List of Essential Medicines for Children), World Health Organization, 2016.

[50] Gelband H., Miller-Petrie M., Pant S., Gandra S., Levinson J., Barter D.,et al., The state of the world's antibiotics 2015, Wound Heal. South. Afr., 2015, 8, 30-34.

[51] IMS Health South Africa: Total Private Market Report, in: MAT (Ed.), January 2011.

[52] Sulieman S.E., Metjian T.A., Zaoutis T.E., Fisher B.T., Pneumocystis pneumonia: epidemiology and options for prophylaxis in Non-HIV immunocompromised pediatric patients, Curr. Fungal Infect. Rep., 2014, 8, 45-55.

[53] Henton M.M., Eagar H.A., Swan G.E., van Vuuren M., Part VI. GARP: Antibiotic management and resistance in livestock production, S. Afr. Med. J., 2011, 101, 583-586.

[54] Davies J., Davies D., Origins and evolution of antibiotic resistance, Microbiol. Mol. Biol. Rev., 2010, 74, 417-433.

[55] Hughes D., Andersson D.I., Evolutionary consequences of drug resistance: shared principles across diverse targets and organisms, Nat. Rev. Genet., 2015, 16, 459-471.

[56] Dye C., Scheele S., Dolin P., Pathania V., Raviglione M.C., Global burden of tuberculosis: estimated incidence, prevalence, and mortality by country, JAMA, 1999, 282, 677686.

[57] Kaufmann S.H., Parida S.K., Tuberculosis in Africa: learning from pathogenesis for biomarker identification, Cell Host Microbe., 2008, 4, 219-228.

[58] Sismanidis C., Glaziou P., Law I., Floyd K., The burden of tuberculosis disease in children, Lancet, 2014, 384, 1343.

[59] Global tuberculosis report 2013, World Health Organization, Geneva, 2013.

[60] Nourzad S., Jenkins H.E., Milstein M., Mitnick C.D., Estimating the global burden of multidrug-resistant tuberculosis among prevalent cases of tuberculosis, Int. J. Tuberc. Lung Dis., 2017, 21, 6-11.

[61] Bantubani N., Kabera G., Connolly C., Rustomjee R., Reddy T., Cohen T., et al., High rates of potentially infectious tuberculosis and multidrug-resistant tuberculosis (MDR-TB) among hospital inpatients in KwaZulu Natal, South Africa indicate risk of nosocomial transmission, PLoS One, 2014, http://journals.plos.org/plosone/article?id=10.1371/journal. pone.0090868.

[62] Quinton L.J., Mizgerd J.P., Dynamics of lung defense in pneumonia: resistance, resilience, and remodeling, Annu. Rev. Physiol., 2015, 77, 407-430.

[63] Nasab S.M.M., Khosravani A., Prevalence of Streptococcus pneumonia in patients diagnosed with pneumonia by culture and PCR, Life Sci. J., 2013, 10, 772-775.

[64] Siemieniuk R.A., Gregson D.B., Gill M.J., The persisting burden of invasive pneumococcal disease in HIV patients: an observational cohort study, BMC Infect. Dis., 2011, https://bmcinfectdis.biomedcentral.com/ articles/10.1186/1471-2334-11-314.

[65] Zar H.J., Hanslo D., Tannenbaum E., Klein M., Argent A., Eley B., et al., Aetiology and outcome of pneumonia in human immunodeficiency virus-infected children hospitalized in South Africa, Acta Paediatr., 2001, 90, 119-125.

[66] Metersky M.L., Ma A., Houck P.M., Bratzler D.W., Antibiotics for bacteremic pneumonia: improved outcomes with macrolides but not fluoroquinolones, Chest, 2007, 131, 466-473.

[67] Chola L., Michalow J., Tugendhaft A., Hofman K., Reducing diarrhoea deaths in South Africa: costs and effects of scaling up essential interventions to prevent and treat diarrhoea in under-five children, BMC Public Health, 2015, 15, 393- 394.

[68] Chhagan M.K., Van den Broeck J., Luabeya K.-K.A., N. Mpontshane, Bennish M.L, Cost of childhood diarrhoea in rural South Africa: exploring cost-effectiveness of universal zinc supplementation., Public Health Nutr., 2014, 17, 21382145.

[69] Baquero F., Martínez J.-L., Cantón R., Antibiotics and antibiotic resistance in water environments, Curr. Opin. Biotechnol., 2008, 19, 260-265.

[70] Peltzer P.M., Lajmanovich R.C., Attademo A.M., Junges C.M., Teglia C.M., Martinuzzi C.,et al., Ecotoxicity of veterinary enrofloxacin and ciprofloxacin antibiotics on anuran amphibian larvae, Environ. Toxicol. Pharmacol., 2017, 51, 114123.

[71] Hamjinda N.S., Chiemchaisri W., Watanabe T., Honda R., Chiemchaisri C., Toxicological assessment of hospital wastewater in different treatment processes, Environ. Sci. Pollut. Res., 2015, 25, 7271-7279.

[72] Haughey S.A., Baxter G.A., Biosensor screening for veterinary drug residues in foodstuffs, J. AOAC Int., 2006, 89, 862-867.

[73] Luo Y., Xu L., Rysz M., Wang Y., Zhang H., Alvarez P.J., Occurrence and transport of tetracycline, sulfonamide, quinolone, and macrolide antibiotics in the Haihe River Basin, China, Environ. Sci. Technol., 2011, 45, 1827-1833.

[74] Ballweber L.R., Baeten L.A., Use of macrocyclic lactones in cattle in the USA, Curr. Pharm. Biotechnol., 2012, 13, 10611069.

[75] Dasenaki M.E., Thomaidis N.S., Multi-residue determination of 115 veterinary drugs and pharmaceutical residues in milk powder, butter, fish tissue and eggs using liquid 
chromatography-tandem mass spectrometry, Anal. Chim. Acta, 2015, 880, 103-121.

[76] Van Wyk J.A., Stenson M.O., Van der Merwe J.S., Vorster R.J., Viljoen P.G., Anthelmintic resistance in South Africa: surveys indicate an extremely serious situation in sheep and goat farming, Onderstepoort J. Vet. Res., 1999, 66, 273-284.

[77] Adegoke A.A., Okoh A.I., Species diversity and antibiotic resistance properties of Staphylococcus of farm animal origin in Nkonkobe Municipality, South Africa, Folia Microbiol. (Praha), 2014, 59m 133-140.

[78] Morley N.J., Environmental risk and toxicology of human and veterinary waste pharmaceutical exposure to wild aquatic host-parasite relationships, Environ. Toxicol. Pharmacol., 2009, 27, 161-175.

[79] Yoshimura H., Endoh Y.S., Acute toxicity to freshwater organisms of antiparasitic drugs for veterinary use., Environ. Toxicol., 2005, 20, 60-66.

[80] Zhang X., Li Y., Liu B., Wang J., Feng C., Gao M., et al., Prevalence of veterinary antibiotics and antibiotic-resistant Escherichia coli in the surface water of a livestock production region in northern China, PLoS One, 2014, http://journals. plos.org/plosone/article?id=10.1371/journal.pone. 0111026 .

[81] Cerami A., Warren K.S., Drugs, Parasitol. Today, 1994, 10, 404406.

[82] Geerts S., Gryseels B., Drug resistance in human helminths: current situation and lessons from livestock, Clin. Microbiol. Rev., 2000, 13, 207-222.

[83] Pullan R.L., Smith J.L., Jasrasaria R., Brooker S.J., Global numbers of infection and disease burden of soil transmitted helminth infections in 2010, Parasit. Vectors, 2014, https://parasitesandvectors.biomedcentral.com/ articles/10.1186/1756-3305-7-37.

[84] Laxminarayan R., Duse A., Wattal C., Zaidi A.K., Wertheim H.F., Sumpradit N., et al., Antibiotic resistance-the need for global solutions, Lancet Infect. Dis., 2013, 13, 1057-1098.

[85] Parida S., Axelsson-Robertson R., Rao M., Singh N., Master I., Lutckii A., et al., Totally drug-resistant tuberculosis and adjunct therapies, J. Intern. Med., 2015, 277, 388-405.

[86] Klopper M., Warren R.M., Hayes C., van Pittius N.C.G., Streicher E.M., Müller B., et al., Emergence and spread of extensively and totally drug-resistant tuberculosis, South Africa, Emerging Infect. Dis., 2013, 19, 449 - 455.

[87] Cullinan K., Pneumonia 'superbug' causes shivers in SA, 2014, https://www.health-e.org.za/2014/04/08/pneumonia-superbug-causes-shivers-sa.

[88] Wang Q.-J., Mo C.-H., Li Y.-W., Gao P., Tai Y.-P., Zhang Y., et al., Determination of four fluoroquinolone antibiotics in tap water in Guangzhou and Macao, Environmental Pollution, 2010, 158, 2350-2358.

[89] Amha Y.M., Anwar M.Z., Kumaraswamy R., Henschel A., Ahmad F., Mycobacteria in municipal wastewater treatment and reuse: Microbial diversity for screening the occurrence of clinically and environmentally relevant species in rrid regions, Environ. Sci. Technol., 2017, 51, 3048-3056.

[90] Liebowitz L., Slabbert M., Huisamen A., National surveillance programme on susceptibility patterns of respiratory pathogens in South Africa: moxifloxacin compared with eight other antimicrobial agents, J. Clin. Pathol., 2003, 56, 344-347.

[91] Brink A., Moolman J., Da Silva M.C., Botha M., Antimicrobial susceptibility profile of selected bacteraemic pathogens from private institutions in South Africa, S. Afr. Med. J., 2007, 97, 273-279.

[92] Perovic O., Singh-Moodley A., Dusé A., Bamford C., Elliott G., Swe-Han K.S., et al., National sentinel site surveillance for antimicrobial resistance in Klebsiella pneumoniae isolates in South Africa, 2010-2012, S. Afr. Med. J., 2014, 104, 563-568.

[93] Mandomando I., Sigaúque B., Morais L., Espasa M., Vallès X., Sacarlal J., et al., Antimicrobial drug resistance trends of bacteremia isolates in a rural hospital in southern Mozambique, Am. J. Trop. Med. Hyg., 2010, 83, 152-157.

[94] Makoka M.H., Miller W.C., Hoffman I.F., Cholera R., Gilligan P.H., Kamwendo D., et al., Bacterial infections in Lilongwe, Malawi: aetiology and antibiotic resistance, BMC Infect. Dis., 2012, 12, 67-74.

[95] Keddy K.H., Sooka A., Crowther-Gibson P., Quan V., Meiring S., Cohen C., et al., Systemic shigellosis in South Africa, Clin. Infect. Dis., 2012, 54, 1448-1454.

[96] Mandomando I., Jaintilal D., Pons M.J., Vallès X., Espasa M., Mensa L., et al., Antimicrobial susceptibility and mechanisms of resistance in Shigella and Salmonella isolates from children under five years of age with diarrhea in rural Mozambique, Antimicrob. Agents Chemother., 2009, 53, 2450-2454.

[97] Eseyin O., Toluyemi S.T., Oni O.O., Investment in Agricultural Sector: Implication for Poverty Reduction in Nigeria (19852012), Am. J. Bus. Soc., 2016, 1, 118-128.

[98] Hendricks R., Pool E.J., The effectiveness of sewage treatment processes to remove faecal pathogens and antibiotic residues, J. Environ. Sci. Health A, 2012, 47, 289-297.

[99] Gumbi B.P., Moodley B., Birungi G., Ndungu P.G., Detection and quantification of acidic drug residues in South African surface water using gas chromatography-mass spectrometry, Chemosphere, 2017, 168, 1042-1050.

[100] Archer E., Petrie B., Kasprzyk-Hordern B., Wolfaardt G.M., The fate of pharmaceuticals and personal care products (PPCPs), endocrine disrupting contaminants (EDCs), metabolites and illicit drugs in a WWTW and environmental waters, Chemosphere, 2017, 174, 437-446.

[101] Ngumba E., Gachanja A., Tuhkanen T., Occurrence of selected antibiotics and antiretroviral drugs in Nairobi River Basin, Kenya, Sci. Total Environ., 2016, 539, 206-213.

[102] K'oreje K., Vergeynst L., Ombaka D., De Wispelaere P., Okoth M., Van Langenhove H., et al., Occurrence patterns of pharmaceutical residues in wastewater, surface water and groundwater of Nairobi and Kisumu city, Kenya, Chemosphere, 2016, 149, 238-244.

[103] Olarinmoye O., Bakare A., Ugwumba O., Hein A., Quantification of pharmaceutical residues in wastewater impacted surface waters and sewage sludge from Lagos, Nigeria, J. Environ. Chem. Ecotoxicol., 2016, 8, 14-24.

[104] Olaitan O.J., Anyakora C., Bamiro T., Tella A.T., Determination of pharmaceutical compounds in surface and underground water by solid phase extraction-liquid chromatography, J. Environ. Chem. Ecotoxicol., 2014, 6, 20-26.

[105] Abou-Elela S., El-Khateeb M., Performance Evaluation Of Activated Sludge Process For Treating Pharmaceutical Wastewater Contaminated With B-Lactam Antibiotics, Journal of Industrial Pollution Control, 2015, 31, 1-5.

[106] Moslah B., Hapeshi E., Jrad A., Fatta-Kassinos D., Hedhili A., Pharmaceuticals and illicit drugs in wastewater samples in 
north-eastern Tunisia, Environ. Sci. Pollut. Res., 2017, 25, 18226-18241.

[107] Tahrani L., Van Loco J., Ben Mansour H., Reyns T., Occurrence of antibiotics in pharmaceutical industrial wastewater, wastewater treatment plant and sea waters in Tunisia.,J. Water Health., 2016, 14, 208-213.

[108] Errayess S.A., Lahcen A.A., Idrissi L., Marcoaldi C., Chiavarini S., Amine A., A sensitive method for the determination of Sulfonamides in seawater samples by Solid Phase Extraction and UV-Visible spectrophotometry, Spectrochim. Acta A, 2017, 181, 276-285.

[109] Dzomba P., Zaranyika M., Kugara J., Zhanda T., Determination of oxytetracycline residues in untreated and treated drinking water in Bindura town by RP-HPLC-UV visible spectrometry after ultrasonic assisted dispersive solid phase extraction (UADSPE), World. J. Pharm. Res., 2014, 3, 1568-1578.

[110] Abegunde D.O., Mathers C.D., Adam T., Ortegon M., Strong K., The burden and costs of chronic diseases in low-income and middle-income countries, Lancet, 2007, 370, 1929-1938.

[111] Weber F.A., Bergmann A., Hickmann S., Ebert I., Hein A., Küster A., Pharmaceuticals in the environment-Global occurrences and perspectives, Environ. Toxicol. Chem., 2016, 35, 823-835.

[112] Díaz-Cruz M.S., Barceló D., Determination of antimicrobial residues and metabolites in the aquatic environment by liquid chromatography tandem mass spectrometry, Anal. Bioanal. Chem., 2006, 386, 973-985.

[113] Chen H., Zhang Y., Gao B., Xu Y., Zhao Q., Hou J., et al., Fast determination of sulfonamides and their acetylated metabolites from environmental water based on magnetic molecularly imprinted polymers, Environ. Sci. Pollut. Res., 2013, 20, 8567-8578. 